\title{
Association of Knowledge, Attitude and Practice of Cleaning Service with the Amount of Mosquito Larvae in Water Container At Bhayangkara Hospital, Palembang, Indonesia
}

\author{
Putri Arini ${ }^{1}$, Chairil Anwar ${ }^{2 \#}$, Husnil Farouk ${ }^{3}$, Novrikasari ${ }^{4}$ \\ ${ }^{1}$ Graduate Student Medical Science, Medical Faculty, Universitas Sriwijaya \\ ${ }^{2}$ Department of Parasitology, Medical Faculty, Universitas Sriwijaya \\ ${ }^{3}$ Department of Public Health Science, Medical Faculty, Universitas Sriwijaya \\ ${ }^{4}$ Faculty of Public Health, Universitas Sriwijaya
}

\section{Received : February $18^{\text {th }} 2018$ \\ Accepted : March 27th 2018}

\# Correspondence $\quad$ :chairil53@yahoo.co.id

Abstract
Bacgkround: Efforts in the eradication of mosquito breeding have been done, but have not shown maximum results due to lack of community participation caused by several factors, such as lack of knowledge, attitude and practice that are considered to play important role in reducing the incidence of vector-borne diseases transmitted by mosquitoes. This study aimed was to determine the relationship of knowledge, attitude and practice of cleaning services with the amount of mosquito larvae at water container around Bhayangkara Hospital Palembang. Populations in this study were 25 cleaning services in Bhayangkara Hospital Palembang.

Methods: Samples in this study were all populations taken by using total sampling technique. Data included the number and types of water containers, the number and species of mosquito larvae found in the water containers, and data of knowledge, attitude and practice of cleaning services. The results were analysed using KruskalWallis statistic test.

Results: There were 75 water containers, 63 water containers were indoors, one of them contains larvae, and 12 water containers were outdoors, the type of two outdoors water containers that contained larvae were plastic buckets. Total larvae that found were 16 larvae of Aedes aegypti. Based on Kruskal-Wallis statistic test, there was no average difference between the number of mosquito larvae based on knowledge with $p>\alpha(0.072>0.05)$, and there was an average difference between the number of mosquito larvae based on attitudewith $p<\alpha$ $(0.006>0.05)$ and practice with $p<\alpha(0.019<0.05)$.

Conclusion: There was a negative association between attitude and practice against the number of mosquito larvae, but not with knowledge.

Keywords: KAP study, mosquito larvae, water container, cleaning services, police hospital

\section{BACKGROUND}

Mosquitoes are one of the most deadly animals in the world. Their ability to carry and spread disease in human causes millions of deaths each year. ${ }^{1}$ Mosquitoes are present in large numbers in tropical and sub-tropical regions of the world. Mosquitoes act as vectors of the disease caused by various parasites and are able to transmit to healthy people through the puncture of the proboscis. The mosquito-borne diseases that pose the greatest threat are malaria transmitted to humans through Anopheles mosquitoes, filariasis by Culexmosquitoes, dengue fever, chikungunya and yellow fever all transmitted to humans via Aedesmosquito. ${ }^{2}$

Dengue fever is transmitted through mosquito bites from the genus Aedes, especially Ae. aegypti and Ae. albopictus. ${ }^{3}$ Data from around the world shows Asia ranks first in the number of dengue fever patients annually. ${ }^{4}$ Meanwhile, from 1968 to 2009, the World Health Organization (WHO) listed Indonesia as the country with the highest dengue fever case in Southeast Asia. ${ }^{4}$ 
To achieve the optimal health status, there has been done various prevention efforts to eradicate mosquitoes by three activities that are draining, closing and burying places of clean water reservoir, bathtub, flower vase and so on, at least once a week, because the mosquitoes breed from egg until maturity within 7-10 days. ${ }^{5}$ As well as survey larva, abatisation and mass fogging. However, these efforts have not shown maximum results due to lack of public participation in efforts to eradicate vectors caused by several factors, such as lack of knowledge and attitudes of the community.

Knowledge, attitudes and behaviors play an important role in reducing the incidence of vector-borne diseases transmitted by mosquitoes. While the actions of someone in eradicating vector borne diseases have been affected by the good knowledge. ${ }^{6}$ However, that does not mean that knowledge can predict the actions that will be done by someone. Not only knowledge and action/behavior alone, but the attitude of a good understanding also affects the self-consciousness of a person. ${ }^{7}$ As Fathiet al. (2005) who said that the attitude of a person who is less good against the prevention and control of illness for example dengue fever can cause outbreaks. ${ }^{8}$ Good knowledge and understanding of cleaning serviceis expected to help in reducing the number of mosquito larvae in the act of eliminating vector. ${ }^{7}$ Infectious diseases such as that all actions of a person are strongly influenced by good knowledge and a positive attitude. ${ }^{9}$

This researchwas important to give information about the type of mosquito larvae in Bhayangkara Hospital Palembang and to know the correlation between knowledge, attitude and behavior of cleaning service with number of mosquito larvae which result can be used as primary prevention for health personnel, as well as the people who live and move around Bhayangkara Hospital Palembang.

\section{Methods}

The type of research used was an analytical survey with cross sectional study design, carried out at Bhayangkara Hospital Palembang and Parasitology Laboratory of Medical Faculty Sriwijaya University.

The target populations in this study were cleaning services. The affordable population in this study was the cleaning service who served in Bhayangkara Hospital Palembang which amounted to 25 people. The sample in this study was an affordable population with total sampling techniques. The dependent variable or dependent variable in this study was the number of mosquito larvae at the water reservoir at Bhayangkara Hospital Palembang. Independent or independent variables in this study were knowledge, attitude and behavior of cleaning services.

The data were arranged in the form of maps, photos and table frequency and processed with the help of computers and made narration. 


\section{Results}

\section{Container types}

There were 75 existing container in the environment Bhayangkara Hospital Palembang. Sixty three containers were water reservoirs, water dispenser containers and plastic buckets were indoors, while 12 containers were plastic cups, buckets of AC water containers, painted buckets, fish ponds and gutters were outdoors. There were three types of positive landfill larvae in the form of two buckets of paint that were outside the room with different locations, and one tub of water reservoir that was in the room. All container positive larvae had a slightly dirty base but the water condition was clear enough. Observations on water reservoirs were shown in the following table.

Table 1. Container Types

\begin{tabular}{|c|c|c|c|c|c|c|c|}
\hline \multirow{3}{*}{ No } & \multirow{3}{*}{$\begin{array}{c}\text { Container } \\
\text { Types }\end{array}$} & \multicolumn{2}{|c|}{ Amount } & \multicolumn{4}{|c|}{ Amount of Positive and Negative } \\
\hline & & \multirow[t]{2}{*}{$\mathbf{n}$} & \multirow[t]{2}{*}{$\%$} & \multicolumn{2}{|c|}{$\begin{array}{l}\text { Positive } \\
\text { Larvae }\end{array}$} & \multicolumn{2}{|c|}{ Negative Larvae } \\
\hline & & & & $\mathbf{n}$ & $\%$ & $\mathbf{n}$ & $\%$ \\
\hline 1. & $\begin{array}{l}\text { Water } \\
\text { container }\end{array}$ & 40 & 53.33 & 1 & 33 & 39 & 54.20 \\
\hline 2. & Plastic bucket & 21 & 28.00 & 0 & 0 & 21 & 29.20 \\
\hline 3. & Plastic cup & 3 & 4.00 & 0 & 0 & 3 & 4.20 \\
\hline 4. & Fish pond & 2 & 2.67 & 0 & 0 & 2 & 2.80 \\
\hline 5. & $\begin{array}{l}\text { Dispenser } \\
\text { water } \\
\text { container }\end{array}$ & 2 & 2.67 & 0 & 0 & 2 & 2.80 \\
\hline 6. & $\begin{array}{l}\text { Bucket of } \\
\text { paint }\end{array}$ & 3 & 4.00 & 2 & 67 & 1 & 1.40 \\
\hline 7. & $\begin{array}{l}\text { AC water } \\
\text { container }\end{array}$ & 1 & 1.33 & 0 & 0 & 1 & 1.40 \\
\hline 8. & Canal & 3 & 4.00 & 0 & 0 & 3 & 4.20 \\
\hline Amount & & 75 & 100.00 & 3 & 100.00 & 72 & 100.00 \\
\hline
\end{tabular}

From Table 1 above, it was found that the type of landfill downloads was a water reservoir with 40 units (53.33\%), found 1 tub (33\%) positive larvae. While from 2 buckets of former paint $(67 \%)$, found positive single larva.

Table 2. Water Container Location

\begin{tabular}{cccccccc}
\hline \multirow{2}{*}{ No } & Water & \multicolumn{2}{c}{ Amount } & \multicolumn{4}{c}{ Positive and Negative } \\
\cline { 3 - 8 } & $\begin{array}{c}\text { Container } \\
\text { Location }\end{array}$ & $\mathbf{n}$ & $\boldsymbol{\%}$ & \multicolumn{2}{c}{ Positive Larvae } & \multicolumn{2}{c}{ Negative Larvae } \\
\cline { 5 - 9 } & Indoor & 63 & 84 & 1 & 33.33 & 62 & 86.11 \\
1 & Outdoor & 12 & 16 & 2 & 66.67 & 10 & 13.89 \\
\hline Total & & 75 & 100 & 3 & 100.00 & 72 & 100.00
\end{tabular}


In Table 2, 75 water containers $(84 \%)$ were found in the room with 1 water container $(33.33 \%)$ positive larvae and the remaining 12 water containers $(16 \%)$ were found outdoors with 2 water containers $(66.67 \%)$ positive larvae.

\section{Number of Larvae}

Table 3. Number of Mosquito Larvae Indoor

\begin{tabular}{llcc}
\hline No & Water Container & $\begin{array}{c}\text { Number } \\
\text { of } \\
\text { Larvae }\end{array}$ & $\begin{array}{c}\text { Contribution } \\
(\boldsymbol{\%})\end{array}$ \\
\hline 1 & Water Reservoir & 3 & 100 \\
2 & Dispenser & 0 & 0 \\
3 & Plastic Bucket & 0 & 0 \\
\hline Total & & $\mathbf{1 0 0}$ \\
\hline
\end{tabular}

From the above Table 3 shows that 3 mosquito larvae (100\%) were found in the water reservoir in the room.

Table 4. Number of Mosquito Larva Outdoors

\begin{tabular}{clcc}
\hline No & Water Container & $\begin{array}{c}\text { Number } \\
\text { of } \\
\text { Larvae }\end{array}$ & $\begin{array}{c}\text { Contribution } \\
(\boldsymbol{\%})\end{array}$ \\
\hline 1 & Plastic cup & 0 & 0 \\
2 & AC water container & 0 & 0 \\
3 & Painted bucket & 13 & 100 \\
4 & Fish pond & 0 & 0 \\
5 & Canal & 0 & 0 \\
\hline Total & $\mathbf{1 3}$ & $\mathbf{1 0 0}$ \\
\hline
\end{tabular}

From the description of the table above shows that found 13 mosquito larvae, which was found in 1 type of water container located in different location as follows. Nine mosquito larvae $(64.28 \%)$ on the paint bucket outside the polyclinic building, and 4 mosquito larvae $(28.57 \%)$ in the paint bucket outside the first class inpatient building.

\section{Genus of Mosquito Larvae}

After capture, mosquito larvae were inserted into clear plastic bottles and observed the larval position at rest. The result was that the larvae form an angle with the water surface at rest as shown in Figure 1, which was one of the hallmarks of the larvae that have a siphon that was the genus Culex and Aedes. The position of the break with the siphon was close to the surface of the water as it aims for breathing. 
Figure 1. Active Position and Rest Position Mosquito Larvae

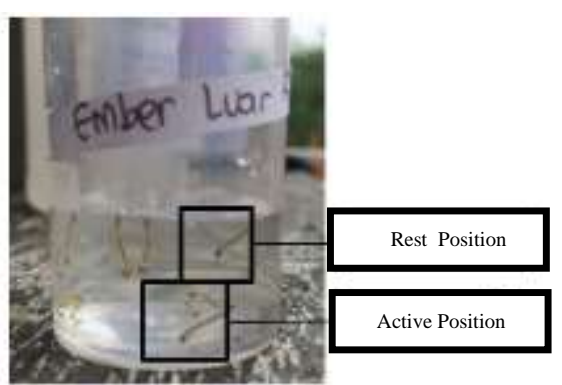

The observations under the microscope were performed to distinguish between these genera with weak magnification, as shown in Figure 2.

Figure 2. Segments 7 and 8 Mosquito larvae

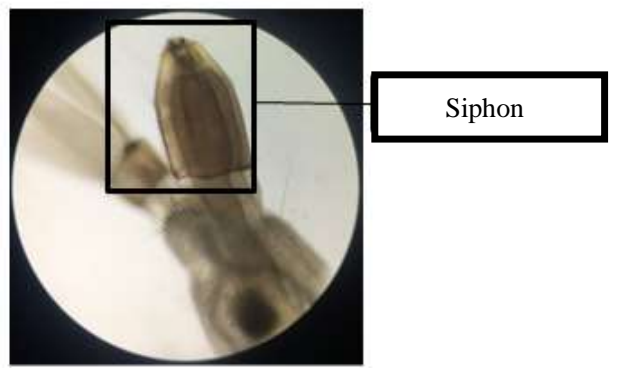

The differences to the four genera can be seen whether or not there was a siphon, a siphon shape and a siphon size. The chubby and short siphon that was characteristic of the genus Aedes. In addition it can be seen that the larvae had a white body until brownish, its size also varies according to its age. The larva undergoes four shifts of skin for about seven days before becoming a pupa.

Figure 3. Lateral Prickly Teeth on Ae. aegypti Larvae (40x10 magnification)

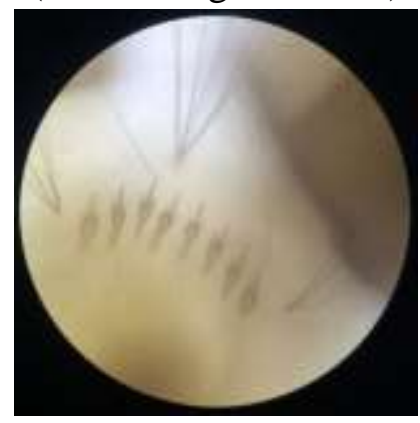


Figure 4. Lateral Speared Teeth on Ae. aegypti Larvae

(100x10 magnification)

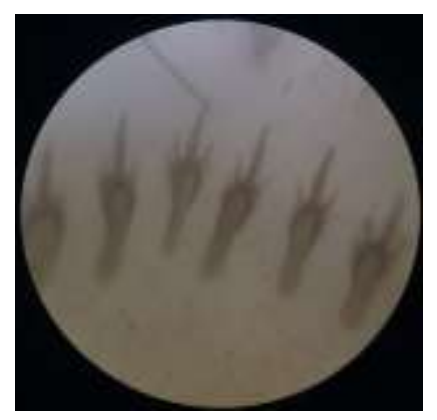

Differences of species from the genus Aedes can be seen whether or not there were lateral spines that exist in segment 8 body mosquito larvae. Ae. albopictus larvae has a lateral non-spiny teeth, while the Ae. aegypti larvae has a lateral spiked tooth on the $8^{\text {th }}$ segment of its body. Figure 3 and 4 above show lateral spiked teeth on Ae. aegypti larvae.

\section{Knowledge Level of Cleaning Service}

Table 5. Frequency Distribution of Knowledge

\begin{tabular}{lcc}
\hline Knowledge Level & $\begin{array}{c}\text { Frequency } \\
(\mathbf{n})\end{array}$ & $\begin{array}{c}\text { Percentage } \\
(\boldsymbol{\%})\end{array}$ \\
\hline Good & 10 & 40 \\
Medium & 13 & 52 \\
Less & 2 & 8 \\
\hline \multicolumn{1}{c}{ Total } & $\mathbf{2 5}$ & $\mathbf{1 0 0}$ \\
\hline
\end{tabular}

Table 5 above shows from 25 respondents who fill the questionnaire, found 10 people had good knowledge of cleaners, 13 people had knowledge of medium and two people had less knowledge.

Knowledge Relation, Attitude and Behavior of Cleaning Services with Number of Mosquito Larvae at Water Reservoir

Table 6. Relationship Number of Mosquito Larvae with Knowledge

\begin{tabular}{lccc}
\hline \multirow{2}{*}{ Knowledge } & \multirow{n}{*}{} & \multicolumn{2}{c}{ Number of Larvae } \\
\cline { 3 - 4 } & & Mean \pm SD & $\boldsymbol{p}$ \\
\hline Good & 10 & $1.300 \pm 2.9833$ & \\
Medium & 13 & $1.692 \pm 2.6890$ & 0.072 \\
Less & 2 & $6.500 \pm 3.5355$ & \\
\hline
\end{tabular}

Table 6 above shows the average number of larvae found in the work area of the cleaning service with less knowledge of $6.500 \pm 3.5355$ more than the average number of larvae found in the work area of cleaners with good knowledge of $1.300 \pm 2.9833$ and moderate 1.692 \pm 2.6890 . Based on statistical test using Kruskal-Wallis obtained $p=0.072$ 
$(p>\alpha)$ means there was no difference of average between the number of mosquito larvae based on knowledge. Post Hoc analysis cannot proceed because it did not met the requirements, where Post Hoc requirement was that there were significant differences $(p<\alpha)$ and independent variables have 3 categories.

Table 7. Relationship Number of Mosquito Larvae with Attitude

\begin{tabular}{|c|c|c|c|}
\hline \multirow{2}{*}{ Attitude } & \multirow{2}{*}{ n } & \multicolumn{2}{|c|}{ Number of Larvae } \\
\hline & & Mean \pm SD & $p$ \\
\hline Good & 21 & $1.333 \pm 2.8166$ & \\
\hline Medium & 4 & $5.000 \pm 2.7080$ & 0.006 \\
\hline
\end{tabular}

Table 7 shows the average number of larvae found in the work area of the cleaning services with a moderate attitude of $5.000 \pm 2.7080$ more than the average number of larvae found in the work area of the cleaning services who has a good attitude of $1.333 \pm 2.8166$. Based on statistical test by using Kruskal-Wallis obtained $p=0.006(p<\alpha)$ mean that there was difference of mean between mosquito larva number based on the cleaning service's attitude. Post Hoc analysis can't proceed because it did not met the requirements, where Post Hoc requirement was that there were significant differences $(p<\alpha)$ and independent variables have three categories.

Table 8. Relationship Number of Mosquito Larvae with Behavior

\begin{tabular}{lrcc}
\hline \multirow{2}{*}{ Behavior } & \multirow{n}{*}{} & \multicolumn{2}{c}{ Number of Larvae } \\
\cline { 3 - 4 } & & Mean \pm SD & $\boldsymbol{p}$ \\
\hline Good & 22 & $1.455 \pm 2.8069$ & 0.019 \\
Medium & 3 & $5.333 \pm 3.2146$ & \\
\hline
\end{tabular}

Table 8 shows the average number of larvae found in the work area of cleaning services with moderate behavior of $5.333 \pm 3.2146$ more than the average number of larvae found in the work area of the cleaning services who had good behavior of $1.455 \pm 2.8069$. Based on statistical test using Kruskal-Wallis, $p=0.019(p<\alpha)$ means that there was an average difference between the number of mosquito larvae based on hygiene behavior. Post Hoc analysis can't proceed because it did not met the requirements, where Post Hoc requirement was that there were significant differences $(p<\alpha)$ and independent variables have three categories.

\section{Discussion}

\section{Potential Mosquito Breeding Habitat}

From the results of research that has been done, found as many as 75 existing water containers in the environment Bhayangkara Hospital Palembang. Sixty three water containers were water reservoirs, water dispenser containers and plastic buckets were indoors, while 12 water containers were plastic cups, buckets of AC water containers, painted buckets, fish ponds and gutters were outdoors. Found three types of positive landfill larvae in the form of 
two bucket of paint which were outdoors with different locations, and 1 tub of water reservoirs that were indoors. All water containers positive larvae had a slightly dirty base but the water condition was clear enough. The three types of water container mentioned above include potential water container to facilitate the breeding of Ae. aegypti mosquitoes.

Ae.aegypti mosquito breeding place is a landfill for domestic purposes and a natural breeding ground in the form of a puddle of trees (Ishartadiati, undate).$^{10}$ It is known that all types of water container in which mosquito larvae are found are water container types for household purposes, which are certainly used for daily activities. The results of this observation are supported by research conducted by Yuwono which states that based on several surveys that have been conducted in several cities in Indonesia shows the most potential breeding place is a water reservoir, tub WC, bucket, jars, drums, and the like. ${ }^{11}$

Ae.aegyptimosquitoelarvae are found to be associated with the availability of food, associated with the base material of the water reservoir. ${ }^{12}$ Based on the type of water container, two of the three water containers found were larvae were dark-colored buckets. This is supported by research by Vezzaniet al. (2002) in Buenos Aires, Argentina found containers with a black plastic base containing many Ae. aegypti larvae (82.1\%), then followed by container with glass base material $(8.5 \%)$, metal $(6 \%)$ and ceramics $(3.4 \%){ }^{13}$ One other landfill was a type of water holding basin in the room. This is supported by the WHO (2003) statement that Aedes mosquitoes are particularly Ae. aegypti, generally prefer places in the room that are not exposed to direct sunlight as their breeding habit. ${ }^{8}$

\section{Number of Mosquito Larvae}

In this study was found as many as 16 mosquito larvae obtained from 2 types of water container at 3 different locations. Two buckets of paint outside of the room with different location. One bucket outside the VIP ward, there was 4 mosquito larvae. One bucket outside the polyclinic building, there was 9 mosquito larvae. One tub of water reservoir in the Emergency Room, there was 3 mosquito larvae.

All positive landfill larvae were a man-made water container type. This was supported by the statement of Chan et al (1971) that in urban areas habitat of Ae. aegypti mosquito varies greatly, but $90 \%$ are human-made containers. ${ }^{14}$

\section{Genus of Mosquito Larvae}

Most Aedes larvae can be distinguished from other genera visibly from their short siphon. ${ }^{15}$ Aedes larvae have short, fat tubes with only one pair of hairtuff. ${ }^{16}$ Ae. aegypti larvae have open saddles and laterally spiny comb teeth. ${ }^{17} A e$. aegypti larvae inhaling oxygen through the posterior siphon that lies above the water surface while the rest of the body hangs vertically. 
After observation, all larvae were found to have white to brownish bodies of varying sizes based on their ages. On the head,it was visible eyes and a pair of antenna. In the eighth segment of the body the larvae were found brownish and short brownish siphon, and in the $7^{\text {th }}$ segment there was lateral spiked tooth that distinguishes 2 species of the genus Aedes. From the description of the above findings it can be concluded that the mosquito larvae found in the environment of Bhayangkara Hospital Palembang was Ae. aegypti larvae.

\section{Knowledge of Cleaning service}

From the research by using questionnaires as a measurement of knowledge level to 25 cleaning service RS Bhayangkara Palembang, the above table shows as many as 10 people have good knowledge, 13 people had medium knowledge, and 2 people have less knowledge. According to previous research by Ravenia (2016), there was a relationship between knowledge with the average number of mosquito larvae. ${ }^{18}$

\section{Knowledge Relation, Attitude and Behavior of Cleaning Service with Number of Mosquito Larvae at Water Reservoir}

Based on previous research conducted in Palembang by Santoso and Budiyanto (2008) said that there is no significant relationship between the level of knowledge, attitudes, and behavior of respondents to Aedes sp larvae. ${ }^{19}$

From Kruskal-Wallis statistic test by looking at the average difference, $p=0.072(p>\alpha)$ shows that there was no average difference between the number of mosquito larvae based on knowledge. In other words, the above statement can be analogised as a statistical relationship between the knowledge of cleaning service with the number of larvae found mosquitoes. The result of this research is reinforced by the results of research conducted by Yudhastuti and Anny (2005) in Wonokusumo Village with Chi-Square statistical test where obtained $p=$ $0.001(p<\alpha)$ means there was a significant relationship between the level of knowledge of respondents with the presence of Ae. aegypti larvae. ${ }^{6}$

Attitude research conducted on 25 cleaning services was performed using Likert scale. From the result of Kruskal-Wallis statistic test by observing the average difference obtained $p$ $=0.006(p<\alpha)$, it shows that there was difference of mean between mosquito larva number based on cleaning service attitude. This means there was no relationship between the numbers of mosquito larvae based on attitude. This was in line with the research of Yudhastuti and Anny (2005) from Fisher's Exact Test statistic which obtained $p=0.13(p>\alpha)$, meaning there was no significant relation between respondent attitude with presence of Ae. aegypti larvae. ${ }^{6}$ Also supported by Ravenia (2016) study using statistical tests with correlation, $p=0.352$ $(p>\alpha)$, statistically, there was no correlation between the number of mosquito larvae to the attitude of the cleaning service. ${ }^{18}$ This may be caused by respondents always answer the question with good things only, as evidenced from the questionnaire results for the attitude of the cleaning services there were 21 cleaning services with good attitude level, while the rest as much as four cleaning services had moderate attitude level. This was contrary to the results of Wulandari (2008) study which says that there was a significant correlation between knowledge and attitude of head of family about PSN program with existence of Ae. aegypti larvae. $^{20}$ 
The research on the behavior of 25 cleaning services at Bhayangkara Palembang Hospital was done by Kruskal-Wallis statistic test and obtained $p=0.019(p<\alpha)$, meaning that there was average difference between mosquito larvae number based on hygiene behavior. This means there was no relationship between the numbers of mosquito larvae based on behavior. This was supported by the results of research conducted by Lerik and Marni (2008) using Fisher's Exact Test statistic obtained $p=0.6997(p>\alpha)$. It means there was no relationship meaningfulness between knowledge variable and behavior of housewife in PSN Dengue Fever. ${ }^{21}$ But the result of research contradict with result of research of Ravenia (2016) with result of statistical test $p=0.008(p<\alpha)$, it can be concluded that there was correlation on hygiene behavior with presence of larva. ${ }^{16}$

\section{Conclusions}

Found 75 landfills, 63 water containers were indoors, with one water container type of larval positive shelter. While the rest, 12 water containers were outdoors, with two water containers type plastic bucket of former larval positive paint. All mosquito larvae found in the water container at Bhayangkara Hospital Palembang which amounted to 16 larvae were Ae. aegypti larvae.The measurement of knowledge level of cleaning service was mostly obtained by medium knowledge, followed by good knowledge, and lack of knowledge.The result of Kruskal-Wallis statistic test shows that there was no average difference between the numbers of mosquito larvae based on the knowledge.Kruskal-Wallis statistical test results show that there was an average difference between the number of mosquito larvae based on the attitude and behavior of cleaning service.

\section{References}

1. WHO. 2017. Mosquito-borne Diseases.

2. WHO. 2016. The Mosquito.

3. Kemenkes RI. 2015. DemamBerdarahBiasanyaMulaiMeningkatdi Januari. Jakarta, Indonesia.

4. Kemenkes RI. 2010. DemamBerdarah Dengue. BuletinJendelaEpidemiologi. Jakarta, Indonesia.

5. Hadi, U.K. 2012. Penyakit Tular Vektor: Demam Berdarah Dengue. Bagian Parasitologi dan Entomologi Kesehatan Fakultas Kedokteran Hewan IPB, Bogor, Indonesia.

6. Yudhastuti, R. danVidiyani, A. 2005. PencegahandanPemberantasanDemam Berdarah Dengue di Indonesia. Jakarta.

7. Azwar, S. 2011. SikapdanPerilaku. Dalam: SikapManusiaTeoridanPengukurannya. EdisikeduaPustakaPelajar, Yogyakarta, hal 3-22.

8. Amaliah, A. 2016.Identifikasi Larva Nyamuk di Tempat-tempat Penampungan Air serta Pengetahuan, Sikap dan Tindakan Petugas Kebersihan Tentang Perkembangbiakan Nyamuk di Kambang Iwak Palembang. FK Universitas Sriwijaya, Palembang, Indonesia, hal. 46.Skripsi. 
9. Anny, W. \& Ririh Yudhastuti. 2004. Hubungan Kondisi Lingkungan, Kontiner, dan Perilaku Masyarakat dengan Keberadaan Jentik Nyamuk Aedes aegypti. FKM Airlangga.

10. Ishartadiati, K. undate. Aedesaegypti sebagaiVektorDemamBerdarah Dengue. FK WijayaKusuma Surabaya. Surabaya. Indonesia.

11. Yotopranoto, S., Sri Subekti, Rosmanida, Sulaiman. 1998. DinamikaPopulasiVektorpadaLokasidenganKasusDemamBerdarah Dengue yang Tinggi di Kotamadya Surabaya. MajalahKedoteran Tropis Indonesia. 9:1-2.

12. Hadi. UK, E. AgustinadanH.S. Singgih. 2009. SebaranJentikNyamukAedes aegypti (Diptera: Culicidae) di DesaCikarawang, Kabupaten Bogor.

13. Vezzani, D. \& N Schweigmann. 2002. Suitability of Container from Different Sources as Breeding Sites of Aedesaegypti (Linnaeus) in a Cementery of Buenos Aires City, Argentina. Bioline International. 6:789-792.

14. Chan, K.L. B.C.Ho. \&Y.C.Chan. 1971. Aedesaegypti (L) and Ae. albopictus (Skuse) in Singapore City. 2 Larval Habitats. Bull. Wld. Health Org. 44: 629-633.

15. CDC. 2012. Mosquito Life-Cycle.

16. CVBD. 2015. General Morphology.

17. Djakaria,S. 2000. VektorPenyakitVirus, Riketsia, SpiroketadanBakteri. Dalam: Srisasi G, Herry DI, Wita P (Penyunting). ParasitologiKedokteran. EdisiKetiga. Balai Penerbit FKUI, Jakarta, hal. 235-237.

18. Ravenia, A. H. 2016. Hubungan Pengetahuan, Sikap danPerilakuPetugasKebersihandenganJumlah Larva NyamukpadaTempat Penampungan Air di WismaAtletJakabaring Palembang. FK Universitas Sriwijaya, Palembang, Indonesia.Skripsi.

19. SantosodanA. Budiyanto. 2008. HubunganPengetahuan, Sikap danPerilaku Masyarakat terhadapVektorDengue Fever di Kota Palembang Provinsi Sumatera Selatan.

20. Purnama, S.J. 2010. HubunganPengetahuandanSikapdenganPerilakuPemberantasanSarangNyamukAedesae gyptipadaKepalaKeluargaDesaBalesonoKecamatanNgunutKabupatenTulungagung. UniversitasSebelasMaret. Surakarta.

21. Lerik, M.D.C. danMarni. $2008 . \quad$ Hubungan antaraPengetahuandanSikapdenganPraktikIbuRumahTanggadalamPemberantasanSaran gNyamukDemamBerdarah Dengue di KelurahanOebufuKecamatanOebobo Kota Kupang. MKM. Volume:03 